\title{
Synthesis of $\mathrm{Ga}_{2} \mathrm{O}_{3}$ powders by precipitation method
}

\author{
Jong-Yeol Jung*,**, Sang-Hun Kim*,**, Eun-Tae Kang**, Kyu-Sung Han*, Jin-Ho Kim*, Kwang-Teak \\ Hwang* and Woo-Seok Cho*,t
}

*Icheon Branch, Korea Institute of Ceramic Engineering and Technology, Icheon 467-843, Korea

**School of Nano and Advanced Materials Engineering, Gyeongsang National University, Jinju 660-701, Korea

(Received December 9, 2013)

(Revised December 30, 2013)

(Accepted January 10, 2014)

Abstract In this study, we investigated synthesis and characteristics of gallium oxide $\left(\mathrm{Ga}_{2} \mathrm{O}_{3}\right)$ powders prepared by precipitation method. $\mathrm{Ga}_{2} \mathrm{O}_{3}$ powders were synthesized using $\mathrm{Ga}\left(\mathrm{NO}_{3}\right)_{3}$ as a starting material and $\mathrm{NH}_{4} \mathrm{OH}$ as a precipitant. The oxidation temperature of $\mathrm{Ga}(\mathrm{OH})_{3}$ and phase transition temperature of $\mathrm{Ga}_{2} \mathrm{O}_{3}$ was revealed using TG-DSC analysis. The crystal structural change of $\mathrm{Ga}_{2} \mathrm{O}_{3}$ powders was investigated by XRD analysis. The morphologies and size distributions of $\mathrm{Ga}_{2} \mathrm{O}_{3}$ particles were analyzed using SEM.

Key words Precipitation, Gallium oxide, Aging, InGaZnO

\section{침전법을 이용한 $\mathrm{Ga}_{2} \mathrm{O}_{3}$ 분말의 합성}

정종열***, 김상훈***, 강은태**, 김진호*, 한규성*, 황광택*, 조우석*,†

*한국세라믹기술원 이천분원, 이천, 467-843

**국립경상대학교 공과대학 재료공학부 재료공학과, 진주, 660-701

(2013년 12월 9일 접수)

(2013년 12월 30일 심사완료)

(2014년 1월 10일 게재확정)

요 약 본 연구에서는 $\mathrm{InGaZnO}$ 반도체를 제조하기 위하여 출발물질로 사용되는 $\mathrm{Ga}_{2} \mathrm{O}_{3}$ 분말을 침전법을 이용하여 합성 하였다. 침전법의 공정 변수인 출발물질로 사용된 $\mathrm{Ga}\left(\mathrm{NO}_{3}\right)_{3}$ 의 농도와 aging 시간 및 온도를 제어하여 $\mathrm{Ga}_{2} \mathrm{O}_{3}$ 분말을 합성하 고 그 물성을 분석하였다. TG-DSC 분석을 통하여 $\mathrm{Ga}(\mathrm{OH})_{3}$ 의 산화온도 및 $\mathrm{Ga}_{2} \mathrm{O}_{3}$ 의 상전이 온도를 확인하였고, XRD 분석 을 통해 $\mathrm{Ga}_{2} \mathrm{O}_{3}$ 의 결정구조와 결정성의 변화를 확인하였다. 또한 $\mathrm{SEM}$ 관찰을 통해 $\mathrm{Ga}_{2} \mathrm{O}_{3}$ 분말의 미세 구조와 평균 입도 및 입도 분포를 분석하였다.

\section{1. 서 론}

TFT(Thin film transistor)는 첨단 디스플레이의 핵심 소자 중 하나로 고해상도, 고속 구동의 디스플레이의 구 현을 위해서는 TFT 반도체 소자의 높은 전하이동도가 필수적이라 할 수 있다. 액정 디스플레이에 사용되는 비 정질 실리콘(amorphous silicon) TFT의 경우 $1 \mathrm{~cm}^{2} / \mathrm{Vs}$ 이하의 낮은 전하이동도로 인하여 대면적 디스플레이에 한계를 보이기 때문에 이러한 비정질 실리콘 $\mathrm{TFT}$ 의 단 점을 보완하기 위해 저온 다결정 실리콘(LTPS, low

\footnotetext{
Corresponding author

Tel: +82-31-645-1405

Fax: +82-31-645-1486

E-mail:wscho@kicet.re.kr
}

temperature poly silicon) TFT가 개발되었다. LTPS TFT 의 경우 $100 \mathrm{~cm}^{2} / \mathrm{Vs}$ 의 높은 전하 이동도를 가지는 장점 이 있으나, 비정질 실리콘에서 다결정 실리콘으로 결정 상의 변화를 주는 공정으로 인해 제조공정이 복잡해지고 가격 경쟁력이 떨어지며, 대형 기판 적용에 어려움이 많 아 소형 디스플레이에만 사용되고 있는 실정이다. 또한 유기물을 이용한 유기물 $\mathrm{TFT}$ 의 경우 $5 \mathrm{~cm}^{2} / \mathrm{Vs}$ 이상의 전하 이동도가 보고되었지만, 복잡한 제조 공정 및 $\mathrm{TFT}$ 로 제조하였을 때 재현성이 부족한 단점이 있다[1-3].

이러한 TFT의 단점을 보완한 IGZO 산화물 TFT의[4] 경우 $\mathrm{In}_{2} \mathrm{O}_{3}$ 는 이동도 개선, $\mathrm{ZnO}$ 는 네트워크 형성제, $\mathrm{Ga}_{2} \mathrm{O}_{3}$ 는 전하억제 및 네트워크 안정제로 역할을 하기 때문에 높은 신뢰성을 가지며[5], 전하 이동도는 $10 \mathrm{~cm}^{2} /$ $\mathrm{Vs}$ 이상의 특성을 가진다. 또한 타겟으로 제조 시에 기 
존에 사용되던 스퍼터 공정에 적용이 가능하여 대면적화 가 용이하고, 공정 비용도 저렴해지는 장점이 있다 $[3,6]$.

이러한 IGZO 산화물 TFT를 만들기 위해서는 출발물 질인 $\mathrm{In}_{2} \mathrm{O}_{3}, \mathrm{ZnO}, \mathrm{Ga}_{2} \mathrm{O}_{3}$ 를 혼합하여 성형 및 소결공정 을 거쳐 타겟으로 제조한 뒤 스퍼터링을 통해 TFT로 만 들게 된다[7]. 이 출발물질들 중 $\mathrm{In}_{2} \mathrm{O}_{3}, \mathrm{ZnO}$ 의 경우 수 십 나노 크기의 분말을 제조하는 공정이 확립되어 있는 반면, $\mathrm{Ga}_{2} \mathrm{O}_{3}$ 의 경우 아직 $4 \sim 5 \mu \mathrm{m}$ 크기의 분말을 사용 하기 때문에 혼합공정에서 입자 크기의 불균일성으로 인 해 타겟의 성분 불균일성이 나타나게 된다. 따라서 $\mathrm{Ga}_{2} \mathrm{O}_{3}$ 분말의 크기를 $\mathrm{In}_{2} \mathrm{O}_{3}, \mathrm{ZnO}$ 와 비슷한 크기로 제조하는 공정은 IGZO 산화물 반도체 응용에 필수적이라 할 수 있다.

세라믹 분말을 제조하는 방법에는 크게 고상법과 액상 법으로 나뉜다. 고상법의 경우 대량생산이 용이한 장점 이 있으나, 고온의 에너지가 가해져 입자의 크기가 매우 커지는 단점을 가지고 있으며, 입도를 낮추기 위해 분쇄 공정을 하게 되면 이 과정에서 불순물의 유입이 쉬운 단 점이 있다[8-10]. 액상법의 경우 침전법, 졸겔법, 수열합 성법 등이 있으며, 침전법은 저온에서 분말합성이 가능 하여 입도가 작고 균일한 분말을 제조할 수 있다는 점과 각 공정 별 변수의 조절을 통해 입도를 조절할 수 있으 며 대량 생산 공정에도 적합하다 $[11,12]$.

따라서 본 연구에서는 침전법의 각 공정 별 주요 변수 인 출발물질의 농도와 aging 시간 및 온도 변화가 $\mathrm{Ga}_{2} \mathrm{O}_{3}$ 입자의 결정 구조 및 미세 구조에 미치는 영향을 분석하 였으며 최종적으로 $1 \mu \mathrm{m}$ 이하의 크기를 가지는 $\mathrm{Ga}_{2} \mathrm{O}_{3}$ 입자를 제조할 수 있는 최적의 조건을 도출하는데 중점 을 두었다.

\section{2. 실험방법}

본 실험에서는 $\mathrm{Ga}$ 금속을 질산 $\left(\mathrm{HNO}_{3}\right.$, Deajung, $\left.1 \mathrm{M}\right)$ 에 녹인 $1 \mathrm{~mol}$ 의 $\mathrm{Ga}\left(\mathrm{NO}_{3}\right)_{3}$ 용액을 사용하였으며, 침전 제로 수산화암모늄 $\left(\mathrm{NH}_{4} \mathrm{OH}\right.$, Deajung, $\left.28 \%\right)$ 을 사용하였 다. 질산 $525 \mathrm{ml}$ 에 $\mathrm{Ga}$ 금속 $69.7 \mathrm{~g}$ 을 넣고 $80^{\circ} \mathrm{C}$ 에서 24 시간 동안 교반하여 $\mathrm{Ga}$ 금속을 용해시킨 후 $1000 \mathrm{ml}$ 가 되도록 증류수를 투입하여 $1 \mathrm{~mol}$ 의 $\mathrm{Ga}\left(\mathrm{NO}_{3}\right)_{3}$ 용액을 제 조하였다. 이후 $\mathrm{Ga}\left(\mathrm{NO}_{3}\right)_{3}$ 용액에 증류수를 추가 투입하 여 $0.2,0.5,0.8 \mathrm{~mol}$ 의 $\mathrm{Ga}\left(\mathrm{NO}_{3}\right)_{3}$ 용액을 제조하였으며, 각 용액에 $\mathrm{NH}_{4} \mathrm{OH}$ 를 투입하여 $\mathrm{pH}$ 를 8 로 맞추어 침전 공 정을 진행하였다. 침전을 시킨 후 결정상의 안정화를 위 해 aging을 진행하였고, aging 공정은 $25,40,80^{\circ} \mathrm{C}$ 에서 $2,12,24$ 시간 동안 진행되었다. Aging이 끝난 후 원심분 리기를 이용하여 3 회 세척하였으며, $100^{\circ} \mathrm{C}$ 에서 24 시간 건조하여 $\mathrm{Ga}(\mathrm{OH})_{3}$ 분말을 얻었다. 얻어진 $\mathrm{Ga}(\mathrm{OH})_{3}$ 분말

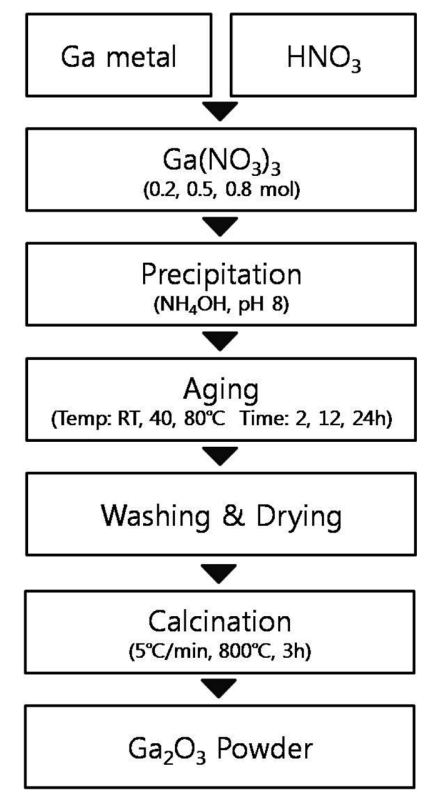

Fig. 1. Experimental procedure of $\mathrm{Ga}_{2} \mathrm{O}_{3}$ powder synthesis by precipitation method.

을 Thermogravimetry - differential scanning calorimetry (TG-DSC, Shimadzu, DTG-60H)를 이용하여 $\mathrm{Ga}_{2} \mathrm{O}_{3}$ 의 결정화 온도 및 상전이 온도를 분석하였으며, $\mathrm{Ga}(\mathrm{OH})_{3}$ 분말을 $800^{\circ} \mathrm{C}$ 에서 3 시간 유지하여 $\mathrm{Ga}_{2} \mathrm{O}_{3}$ 분말을 제조하 였다. Fig. 1에 본 실험의 침전법 공정도를 나타내었다.

합성된 $\mathrm{Ga}_{2} \mathrm{O}_{3}$ 의 결정구조를 확인하기 위해 X-ray diffactometer (XRD, Rigaku, D/2500VL/PC)를 이용하 여 분석을 수행하였으며 입자의 크기와 형상을 확인하기 위해 Field emission scanning electron microscope (FE-SEM, Jeol, JSM-6390) 분석을 행하였다.

\section{3. 결과 및 고찰}

\section{1. $\mathrm{Ga}(\mathrm{OH})_{3}$ 분말의 결정화 및 상전이 온도 분석}

$\mathrm{Ga}_{2} \mathrm{O}_{3}$ 의 결정화 및 상전이 온도를 분석하기 위하여 $0.8 \mathrm{~mol}$ 의 $\mathrm{Ga}\left(\mathrm{NO}_{3}\right)_{3}$ 용액을 $\mathrm{pH}$ 8에서 침전시킨 후, $80^{\circ} \mathrm{C}$ 에서 24 시간 동안 aging 하여 얻은 $\mathrm{Ga}(\mathrm{OH})_{3}$ 분말을 이 용하여 TG-DSC 분석을 실시하였고 그 결과를 Fig. 2에 나타내었다. TG-DSC 분석은 공기 분위기에서 $5^{\circ} \mathrm{C} / \mathrm{min}$ 의 승온 속도로 상온에서 $1000^{\circ} \mathrm{C}$ 까지 측정되었다. $\mathrm{TGA}$ 결과에서 보이듯이 상온에서 $400^{\circ} \mathrm{C}$ 의 구간까지 약 $14 \%$ 의 중량감소가 일어났으며 그 이후의 온도에서는 중량 감소가 거의 관찰되지 않았다. 그리고 $\mathrm{DSC}$ 결과에서 약 $300^{\circ} \mathrm{C}$ 에서부터 $400^{\circ} \mathrm{C}$ 까지 흡열반응이 관찰되었으며, $742^{\circ} \mathrm{C}$ 에서는 발열반응이 관찰되었다. 이러한 결과로 미 루어 보아 $\mathrm{Ga}(\mathrm{OH})_{3}$ 가 $\mathrm{Ga}_{2} \mathrm{O}_{3}$ 로 산화되는 온도구간은 


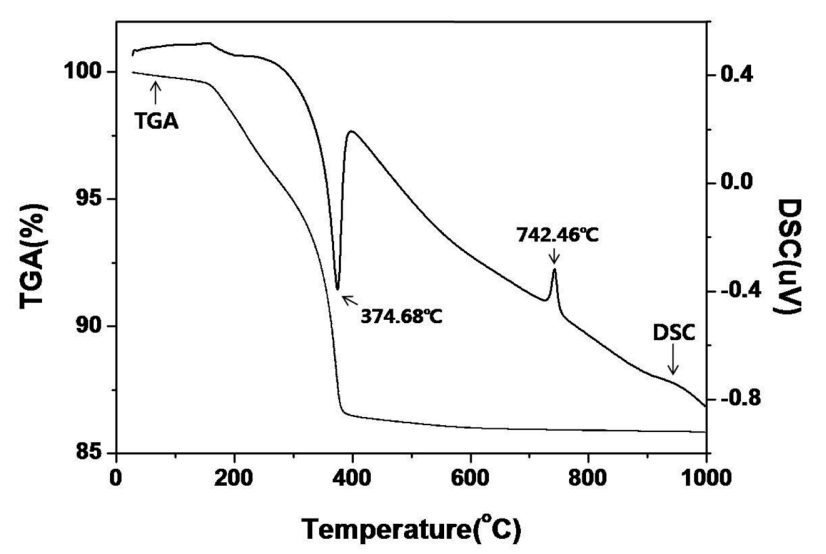

Fig. 2. TG-DSC results of the $\mathrm{Ga}(\mathrm{OH})_{3}$ in static air with the heating rate of $5^{\circ} \mathrm{C} / \mathrm{min}$.

$300^{\circ} \mathrm{C}$ 에서 $400^{\circ} \mathrm{C}$ 사이라는 것을 알 수 있으며, $\alpha-\mathrm{Ga}_{2} \mathrm{O}_{3}$ 인 Rhombohedral 결정구조에서 $\beta-\mathrm{Ga}_{2} \mathrm{O}_{3}$ 인 Monoclinic 결정구조로 상전이가 일어나는 온도는 $740^{\circ} \mathrm{C}$ 부근이라 는 것을 확인하였다 $[13,14]$.

3.2. $\mathrm{Ga}\left(\mathrm{NO}_{3}\right)_{3}$ 용액의 농도에 따른 $\mathrm{Ga}_{2} \mathrm{O}_{3}$ 입자의 특성 분석

$0.2,0.5,0.8 \mathrm{~mol}$ 의 $\mathrm{Ga}\left(\mathrm{NO}_{3}\right)_{3}$ 용액을 이용하여 $\mathrm{pH} 8$ 에서 침전을 시킨 후, $80^{\circ} \mathrm{C}$ 에서 24시간 동안 aging하여 얻은 $\mathrm{Ga}(\mathrm{OH})_{3}$ 분말을 열처리하여 $\mathrm{Ga}_{2} \mathrm{O}_{3}$ 분말을 합성하 였다. Fig. 3(a)는 $\mathrm{Ga}\left(\mathrm{NO}_{3}\right)_{3}$ 의 농도에 따른 $\mathrm{Ga}_{2} \mathrm{O}_{3}$ 분말 의 XRD 분석 결과이다. $0.2,0.5,0.8 \mathrm{~mol}$ 의 $\mathrm{Ga}\left(\mathrm{NO}_{3}\right)_{3}$ 용액을 이용하여 합성한 $\mathrm{Ga}_{2} \mathrm{O}_{3}$ 는 모두 monoclinic 결정 구조를 나타내고 있으며, (401)면에 해당하는 피크 $\left(30.484^{\circ}\right)$ 가 intensity가 가장 강한 피크인 것으로 확인되 었다. 또한 합성된 $\mathrm{Ga}_{2} \mathrm{O}_{3}$ 분말의 결정성을 확인하기 위 해 (111)면에 해당하는 피크 $\left(35.179^{\circ}\right)$ 의 반가폭(FWHM, full width at half maximum)값을 측정하였으며, Scherrer equation (1)을 이용하여 grain size를 계산하여 Fig. 3(b)에 나타내었다.

$$
\tau=\frac{0.9 \cdot \lambda}{\beta \cdot \cos \theta}
$$

$\tau$ 는 grain size를 나타내며, $\lambda$ 는 $\mathrm{Cu} K \alpha$ radiation에 대한 $\mathrm{X}$ 선 파장으로 $1.541 \AA$ 이고, $\beta$ 는 최대 세기를 갖는 peak의 반가폭, $\theta$ 는 회절각을 나타낸다. $\mathrm{Ga}\left(\mathrm{NO}_{3}\right)_{3}$ 용액 의 농도가 0.2 에서 $0.8 \mathrm{~mol}$ 로 증가함에 따라 반가폭값이 0.342 에서 0.329 로 감소하여 $\mathrm{Ga}_{2} \mathrm{O}_{3}$ 분말의 결정성이 증 가하였으며, grain size는 $29 \mathrm{~nm}$ 에서 $30.5 \mathrm{~nm}$ 로 증가하 는 것을 볼 수 있었다.

다음은 합성된 $\mathrm{Ga}_{2} \mathrm{O}_{3}$ 분말의 미세구조 변화를 SEM 을 이용하여 분석하였다. Fig. 4(a) (c)는 $\mathrm{Ga}\left(\mathrm{NO}_{3}\right)_{3}$ 의 농 도에 따른 $\mathrm{Ga}_{2} \mathrm{O}_{3}$ 분말의 $\mathrm{SEM}$ 사진이다. $0.2 \mathrm{~mol}$ 의 $\mathrm{Ga}\left(\mathrm{NO}_{3}\right)_{3}$ 용액으로 제조된 $\mathrm{Ga}_{2} \mathrm{O}_{3}$ 분말의 경우 타원모양 의 약 $1 \mu \mathrm{m}$ 크기를 가진 입자가 관찰되었다. $\mathrm{Ga}\left(\mathrm{NO}_{3}\right)_{3}$ 용액의 농도가 $0.5 \mathrm{~mol}$ 로 증가된 경우 $\mathrm{Ga}_{2} \mathrm{O}_{3}$ 분말은 약 $2 \mu \mathrm{m}$ 크기의 침상 입자가 관찰되었으며, $0.8 \mathrm{~mol}$ 의 $\mathrm{Ga}\left(\mathrm{NO}_{3}\right)_{3}$ 용액으로 제조된 $\mathrm{Ga}_{2} \mathrm{O}_{3}$ 분말의 경우 축 방향 으로 약 $4 \sim 5 \mu \mathrm{m}$ 크기를 가지는 침상 입자가 관찰되었다. 따라서 $\mathrm{SEM}$ 을 이용한 관찰 결과 $\mathrm{Ga}\left(\mathrm{NO}_{3}\right)_{3}$ 의 농도가 증가할수록 $\mathrm{Ga}_{2} \mathrm{O}_{3}$ 입자의 형상이 타원에서 침상으로 성 장하여 입자 크기가 증가하는 것으로 확인되었다.

$\mathrm{Ga}_{2} \mathrm{O}_{3}$ 입자 크기의 경향성을 정량적으로 분석하기 위 해서 SEM 사진에서 임의의 입자 $\mathrm{z}$ 축 길이를 측정하여 입도 분포 및 평균 입자 크기를 Fig. 4(d)에 나타내었다. $\mathrm{Ga}\left(\mathrm{NO}_{3}\right)_{3}$ 용액의 농도가 $0.2 \mathrm{~mol}$ 인 경우 $\mathrm{Ga}_{2} \mathrm{O}_{3}$ 분말은 $0.8 \sim 1.6 \mu \mathrm{m}$ 의 입도 분포를 보였으며, 그 평균 크기는 $1.164 \mu \mathrm{m}$ 로 측정되었다. $0.5 \mathrm{~mol}$ 의 $\mathrm{Ga}\left(\mathrm{NO}_{3}\right)_{3}$ 용액이 사 용된 $\mathrm{Ga}_{2} \mathrm{O}_{3}$ 분말의 경우 $1.4 \sim 3.0 \mu \mathrm{m}$ 의 입도 분포와 $2.278 \mu \mathrm{m}$ 의 평균 크기를 보였으며, $0.8 \mathrm{~mol}$ 의 $\mathrm{Ga}\left(\mathrm{NO}_{3}\right)_{3}$ 용액이 사용된 $\mathrm{Ga}_{2} \mathrm{O}_{3}$ 분말의 경우 $2.2 \sim 5.4 \mu \mathrm{m}$ 의 가장 넓은 입도 분포가 관찰되었고 그 평균 크기는 $4.224 \mu \mathrm{m}$ 로 측정되었다. $\mathrm{Ga}\left(\mathrm{NO}_{3}\right)_{3}$ 용액의 농도에 따른 입자의
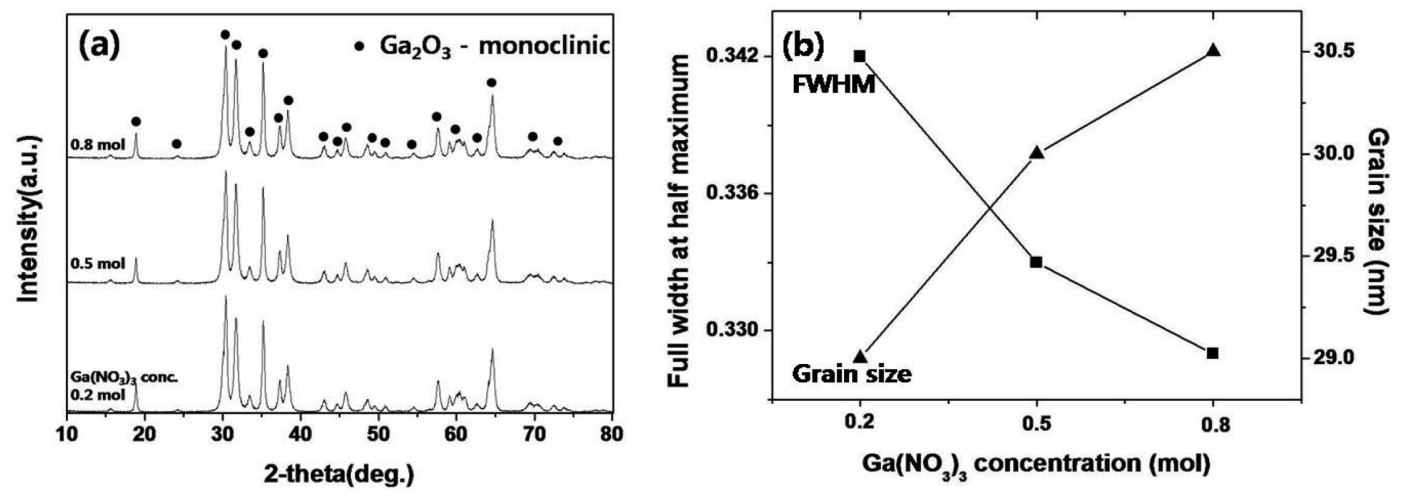

Fig. 3. (a) XRD patterns of $\mathrm{Ga}_{2} \mathrm{O}_{3}$ powder synthesized with $0.2,0.5,0.8 \mathrm{~mol}$ of $\mathrm{Ga}\left(\mathrm{NO}_{3}\right)_{3}$ and (b) FWHM values and grain size from XRD peak at $35.179^{\circ}$ corresponding to (111) plane of $\mathrm{Ga}_{2} \mathrm{O}_{3}$. 

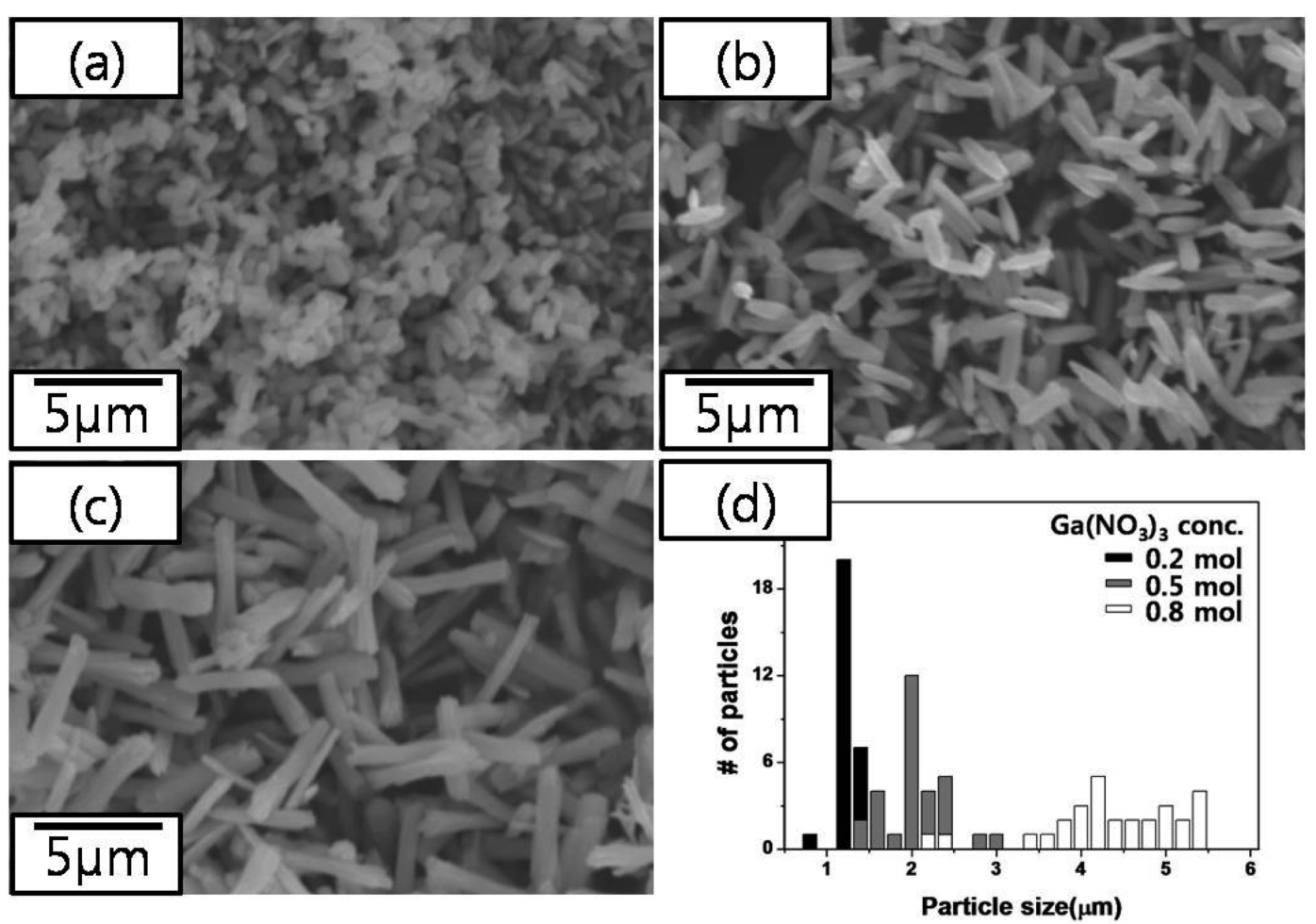

Fig. 4. SEM images of $\mathrm{Ga}_{2} \mathrm{O}_{3}$ powder synthesized with (a) $0.2 \mathrm{~mol}$, (b) $0.5 \mathrm{~mol}$, (c) $0.8 \mathrm{~mol}$ of $\mathrm{Ga}\left(\mathrm{NO}_{3}\right)_{3}$ and (d) particle size distributions.

크기와 그 분포를 확인한 결과 $\mathrm{Ga}\left(\mathrm{NO}_{3}\right)_{3}$ 용액의 농도가 증가할수록 입자의 크기가 증가할 뿐만 아니라 입도 분 포도 넓어지는 것을 확인할 수 있었다.

\subsection{Aging 시간에 따른 $\mathrm{Ga}_{2} \mathrm{O}_{3}$ 입자의 특성 분석}

$\mathrm{Ga}\left(\mathrm{NO}_{3}\right)_{3}$ 용액의 농도 변화에 따른 $\mathrm{Ga}_{2} \mathrm{O}_{3}$ 분말의 입 도 분석 결과 가장 작은 입도 분포를 나타내는 $0.2 \mathrm{~mol}$ 의 $\mathrm{Ga}\left(\mathrm{NO}_{3}\right)_{3}$ 용액을 이용하여 aging조건 변화가 $\mathrm{Ga}_{2} \mathrm{O}_{3}$ 분말의 특성에 미치는 영향을 알아보았다. Fig. 5(a)는 $0.2 \mathrm{~mol}$ 의 $\mathrm{Ga}\left(\mathrm{NO}_{3}\right)_{3}$ 용액을 이용하여 $\mathrm{pH}$ 8에서 침전을
시킨 후, $80^{\circ} \mathrm{C}$ 에서 각각 $2,12,24$ 시간 동안 aging하여 얻 은 $\mathrm{Ga}(\mathrm{OH})_{3}$ 분말을 열처리 하여 얻은 $\mathrm{Ga}_{2} \mathrm{O}_{3}$ 분말의 XRD 분석 결과이다. 얻어진 $\mathrm{Ga}_{2} \mathrm{O}_{3}$ 분말은 모두 monoclinic 결 정구조를 나타내고 있으며, aging 시간이 12시간에서 24 시간으로 증가하자 intensity가 가장 강한 피크가 $\mathrm{Ga}_{2} \mathrm{O}_{3}$ 의(111)면에 해당하는 피크 $\left(35.179^{\circ}\right)$ 에서 (401)면에 해당 하는 피크 $\left(30.484^{\circ}\right)$ 로 바뀌는 것을 확인하였다. 합성된 $\mathrm{Ga}_{2} \mathrm{O}_{3}$ 분말의 결정성 변화를 확인하기 위해 (111)면에 해당하는 피크 $\left(35.179^{\circ}\right)$ 의 반가폭 값을 측정하였으며, grain size를 계산하여 Fig. 5(b)에 나타내었다. aging 시 간이 2시간에서 24 시간으로 증가함에 따라 반가폭 값이
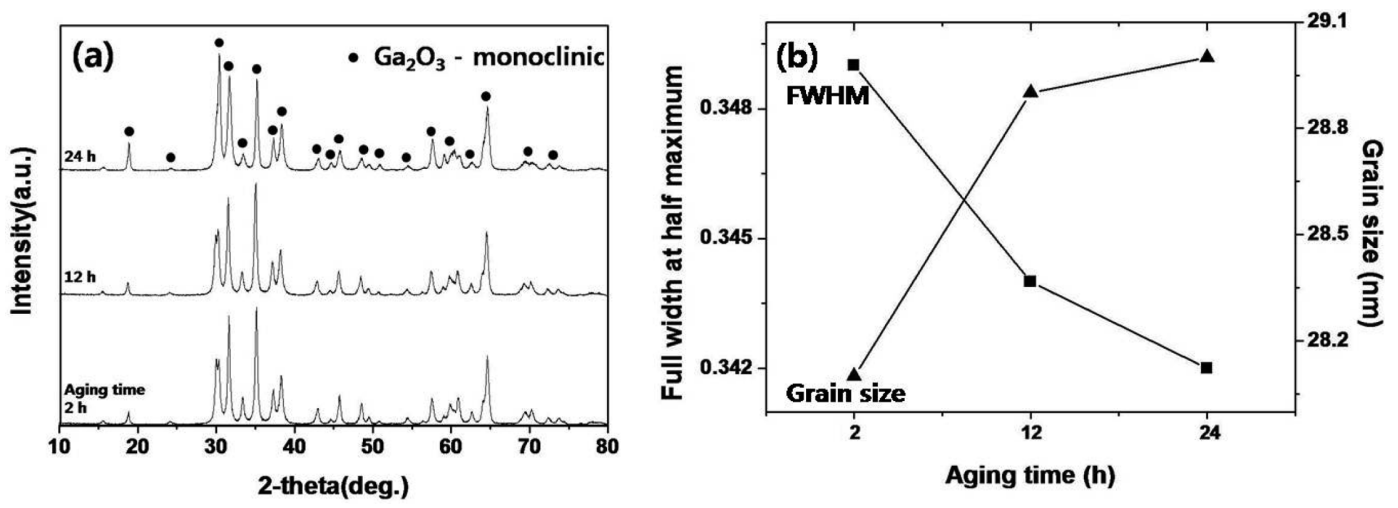

Fig. 5. (a) XRD patterns of $\mathrm{Ga}_{2} \mathrm{O}_{3}$ powder aged at $80^{\circ} \mathrm{C}$ for $2,12,24 \mathrm{~h}$ and (b) FWHM values and grain size from XRD peak at $35.179^{\circ}$ corresponding to (111) plane of $\mathrm{Ga}_{2} \mathrm{O}_{3}$. 


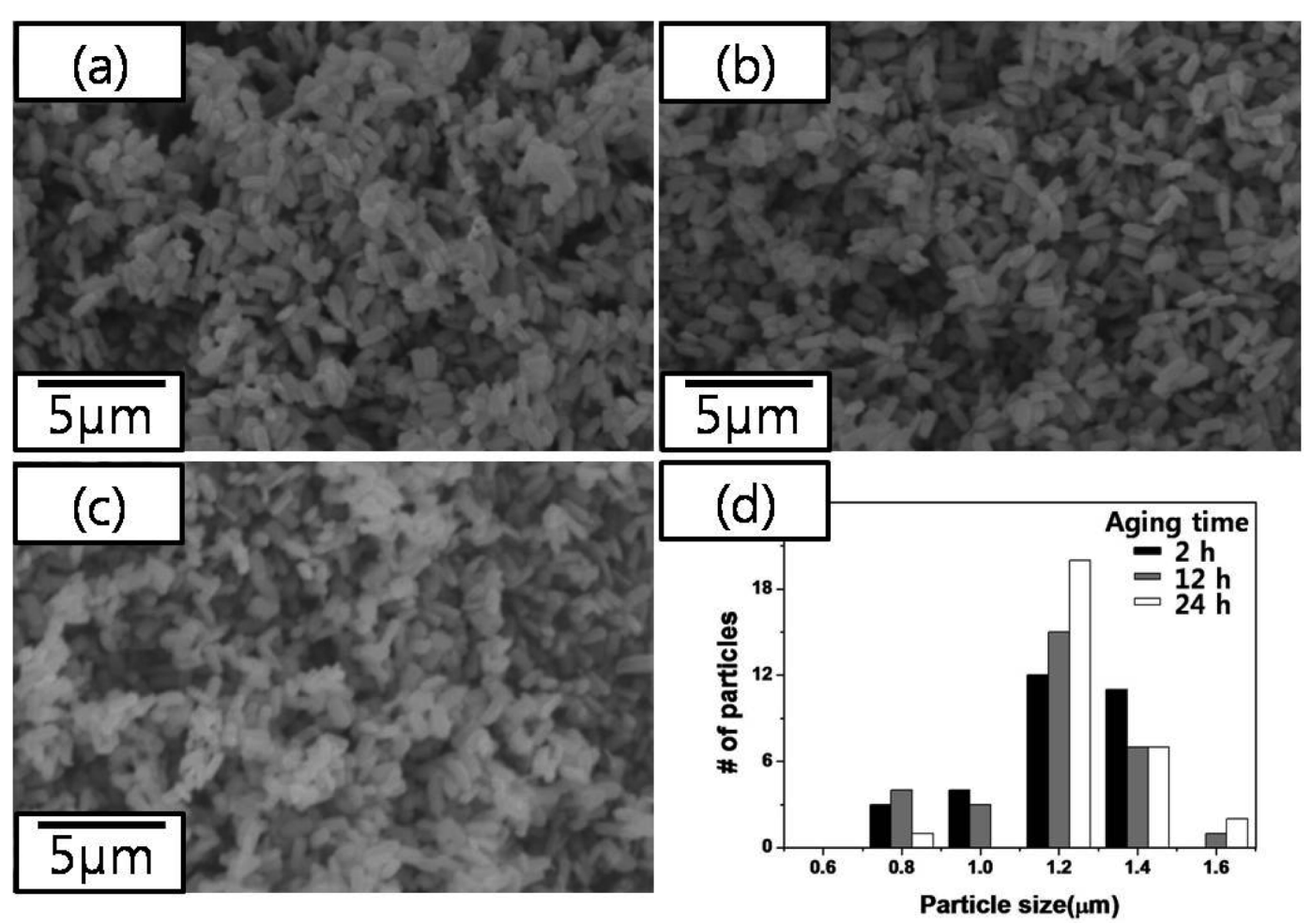

Fig. 6. SEM images of $\mathrm{Ga}_{2} \mathrm{O}_{3}$ powder aged at $80^{\circ} \mathrm{C}$ for (a) $2 \mathrm{~h}$, (b) $12 \mathrm{~h}$, (c) $24 \mathrm{~h}$ and (d) particle size distributions.

0.349 에서 0.342 로 감소하여 결정성이 증가하는 것을 볼 수 있었으며, grain size는 $28.2 \mathrm{~nm}$ 에서 $29 \mathrm{~nm}$ 으로 증가하 였다. 위의 결과에서 aging 시간이 증가하면서 intensity가 가장 강한 피크가 바뀌는 것은 $\mathrm{Ga}_{2} \mathrm{O}_{3}$ 입자가 (401)면으로 성장하면서 결정구조가 더 안정화되기 때문으로 판단된다.

다음은 합성된 $\mathrm{Ga}_{2} \mathrm{O}_{3}$ 분말의 미세구조 변화를 $\mathrm{SEM}$ 을 이용하여 분석하였다. Fig. 6(a) (c)는 aging 시간에 따른 $\mathrm{Ga}_{2} \mathrm{O}_{3}$ 분말의 SEM 사진이다. 모든 조건의 $\mathrm{Ga}_{2} \mathrm{O}_{3}$ 분말에서 타원모양의 약 $1 \mu \mathrm{m}$ 크기를 가진 입자가 관찰 되었다. $\mathrm{Ga}_{2} \mathrm{O}_{3}$ 입자의 입도 분포 및 평균 입자 크기를 Fig. 6(d)에 나타내었다. 2시간 aging한 $\mathrm{Ga}_{2} \mathrm{O}_{3}$ 분말의 경우 $0.6 ~ 1.4 \mu \mathrm{m}$ 의 분포를 보였으며, 그 평균 크기는 $1.114 \mu \mathrm{m}$ 로 측정되었으며, 12 시간 aging한 $\mathrm{Ga}_{2} \mathrm{O}_{3}$ 분말 의 경우 $0.6 \sim 1.6 \mu \mathrm{m}$ 의 분포를 보였으며, 그 평균 크기는 $1.121 \mu \mathrm{m}$ 로 측정되었다. 그리고 24시간 aging한 $\mathrm{Ga}_{2} \mathrm{O}_{3}$ 분말의 경우 $0.6 ~ 1.6 \mu \mathrm{m}$ 의 분포를 보였으며, 그 평균 크 기는 $1.164 \mu \mathrm{m}$ 로 측정되었다. 따라서 aging 시간에 따 른 입자의 크기와 그 분포를 확인한 결과 aging 시간이 증가할수록 입자의 크기가 다소 증가하는 것을 확인할 수 있었으나 그 차이는 매우 작으며 입도 분포도 거의 동일한 것으로 확인되었다.

\subsection{Aging 온도에 따른 $\mathrm{Ga}_{2} \mathrm{O}_{3}$ 입자의 특성 분석}

Aging 온도에 따른 $\mathrm{Ga}_{2} \mathrm{O}_{3}$ 분말의 특성을 분석하기 위
해 $0.2 \mathrm{~mol}$ 의 $\mathrm{Ga}\left(\mathrm{NO}_{3}\right)_{3}$ 용액을 이용하여 $\mathrm{pH}$ 8에서 침 전을 시킨 후, 각각 $25,40,80^{\circ} \mathrm{C}$ 에서 2 시간 동안 aging 하여 얻은 $\mathrm{Ga}(\mathrm{OH})_{3}$ 분말을 열처리 하여 $\mathrm{Ga}_{2} \mathrm{O}_{3}$ 분말을 합성하였다. Fig. 7(a)는 aging 온도에 따른 $\mathrm{Ga}_{2} \mathrm{O}_{3}$ 분말 의 $\mathrm{XRD}$ 분석 결과로 얻어진 $\mathrm{Ga}_{2} \mathrm{O}_{3}$ 분말은 모두 monoclinic 결정 구조로 확인되었다. $35.179^{\circ}$ 에 나타나 는 $\mathrm{Ga}_{2} \mathrm{O}_{3}$ 의 (111)면에 해당하는 피크의 intensity가 가장 강하게 확인되었으며 반가폭 값과 grain size를 측정하여 Fig. 7(b)에 나타내었다. aging 온도가 $25^{\circ} \mathrm{C}$ 에서 $80^{\circ} \mathrm{C}$ 로 증가함에 따라 0.355 에서 0.349 로 감소하여 $\mathrm{Ga}_{2} \mathrm{O}_{3}$ 의 결 정성이 증가하였으며, grain size는 $27.6 \mathrm{~nm}$ 에서 $28.2 \mathrm{~nm}$ 로 커지는 것을 볼 수 있었다.

Fig. 8(a) (c)는 aging 온도에 따른 $\mathrm{Ga}_{2} \mathrm{O}_{3}$ 분말의 $\mathrm{SEM}$ 사진이다. $25^{\circ} \mathrm{C}$ 에서 aging한 $\mathrm{Ga}_{2} \mathrm{O}_{3}$ 분말의 경우 구형에 가까운 입자의 형상을 가지고 있었으며, 그 크기 는 약 $1 \mu \mathrm{m}$ 이하인 것으로 관찰되었고, $40,80^{\circ} \mathrm{C}$ 에서 aging한 $\mathrm{Ga}_{2} \mathrm{O}_{3}$ 분말의 경우 타원모양의 약 $1 \mu \mathrm{m}$ 크기를 가진 입자가 관찰되었다. Fig. 8(d)에서 입도 분포 및 평 균 입자 크기를 분석한 결과 aging 온도에 관계없이 모 든 $\mathrm{Ga}_{2} \mathrm{O}_{3}$ 분말은 약 $0.8 \sim 1.4 \mu \mathrm{m}$ 의 입도 분포를 보였다. $\mathrm{Ga}_{2} \mathrm{O}_{3}$ 의 평균 크기는 $25^{\circ} \mathrm{C}$ 에서 aging 했을 경우 0.937 $\mu \mathrm{m}$ 로 측정되었으며, $40^{\circ} \mathrm{C}$ 에서 aging한 $\mathrm{Ga}_{2} \mathrm{O}_{3}$ 의 경우 $1.069 \mu \mathrm{m}, 80^{\circ} \mathrm{C}$ 에서 aging한 $\mathrm{Ga}_{2} \mathrm{O}_{3}$ 의 경우 $1.114 \mu \mathrm{m}$ 로 측정되어 aging 온도가 증가할수록 입도 분포는 동일하나 평균 입자 크기가 다소 증가하는 것을 확인할 수 있었다. 

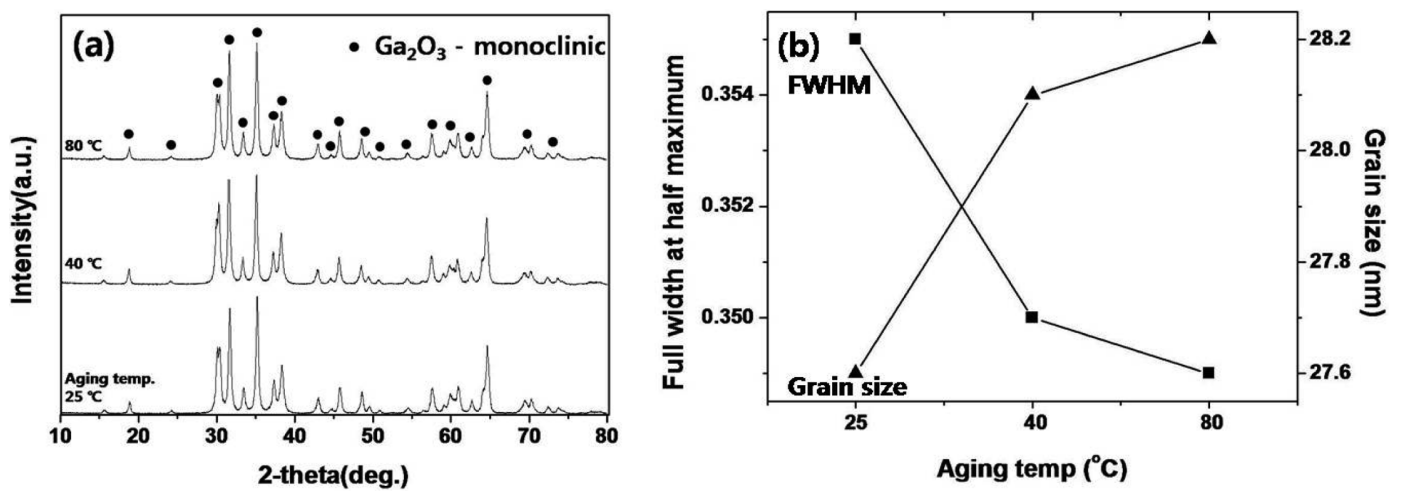

Fig. 7. XRD patterns of $\mathrm{Ga}_{2} \mathrm{O}_{3}$ powder aged for $2 \mathrm{~h}$ at $25,40,80^{\circ} \mathrm{C}$ and (b) FWHM values and grain size from XRD peak at $35.179^{\circ}$ corresponding to (111) plane of $\mathrm{Ga}_{2} \mathrm{O}_{3}$.
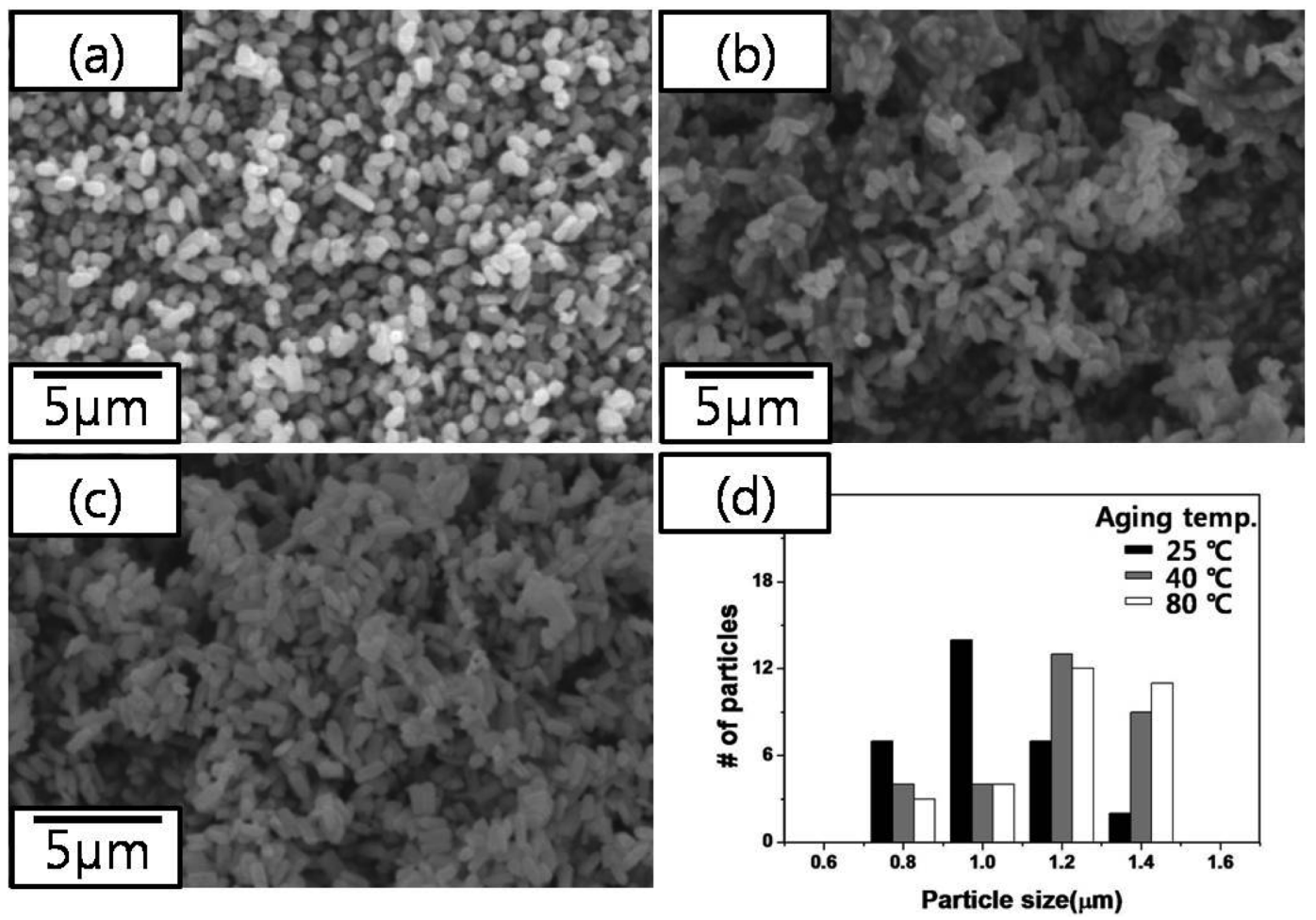

Fig. 8. SEM images of $\mathrm{Ga}_{2} \mathrm{O}_{3}$ powder aged for $2 \mathrm{~h}$ at (a) $25^{\circ} \mathrm{C}$, (b) $40^{\circ} \mathrm{C}$, (c) $80^{\circ} \mathrm{C}$ and (d) particle size distributions.

\section{4. 결 론}

본 연구에서는 침전법을 이용하여 $\mathrm{Ga}$ 금속으로부터 $\mathrm{Ga}_{2} \mathrm{O}_{3}$ 분말을 합성하였다. TG-DSC 분석을 통해 $\mathrm{Ga}(\mathrm{OH})_{3}$ 가 $\mathrm{Ga}_{2} \mathrm{O}_{3}$ 로 산화되는 온도구간은 $300 ~ 400^{\circ} \mathrm{C}$ 사이임을 확인하였고, $\alpha$ 상에서 $\beta$ 상으로 상전이가 일어나는 온도 는 $740^{\circ} \mathrm{C}$ 부근임을 확인하였다. $\mathrm{Ga}_{2} \mathrm{O}_{3}$ 분말을 합성한 후 XRD 분석을 통해 결정구조를 관찰하였는데 $\beta$ 상인 monoclinic의 $\mathrm{Ga}_{2} \mathrm{O}_{3}$ 가 생성된 것으로 관찰되었고 $\mathrm{Ga}\left(\mathrm{NO}_{3}\right)_{3}$ 의 농도, aging 시간 및 온도가 증가할수록 결정성이 향 상되는 결과를 보였다. 합성한 $\mathrm{Ga}_{2} \mathrm{O}_{3}$ 분말의 $\mathrm{SEM}$ 분 석 결과 $\mathrm{Ga}\left(\mathrm{NO}_{3}\right)_{3}$ 용액의 농도가 낮아질수록, aging 시
간 및 온도가 감소할수록 분말의 크기는 작아졌다. 0.2 $\mathrm{mol}$ 의 $\mathrm{Ga}\left(\mathrm{NO}_{3}\right)_{3}$ 용액을 이용하여 침전시킨 후 $25^{\circ} \mathrm{C}$ 에서 2시간 동안 aging한 $\mathrm{Ga}_{2} \mathrm{O}_{3}$ 분말이 가장 작은 입 자 크기를 보였으며, 그 평균 크기는 $0.936 \mu \mathrm{m}$ 로 측정 되었다.

\section{감사의 글}

본 연구는 2013년도 지식경제부의 재원으로 한국에너 지 기술평가원(KETEP)의 지원을 받아 수행한 연구 과 제입니다(20125020100010). 


\section{참 고 문 헌}

[1] J.K. Jeong, "Next-generation displays for oxide TFT technology development trend", KIEE 23 (2010) 24.

[2 ] S.K. Park, M.S. Oh and Y.H. Kim, "Oxide TFT technology trend of large-area display for a solution process", KIEE 25 (2012) 12.

[3] H.J. Kim and B.S. Bea, "LCD TFT technology and recent trend", Phys. High Technol. 17 (2008) 10.

[ 4 ] K. Nomura, H. Ohta, A. Takagi, T. Kamiya, M. Hirano and H. Hosono, "Room-temperature fabrication of transparent flexible thin-film transistors using amorphous oxide semiconductors", Nature 432 (2004) 488.

[ 5 ] H. Hosono, "Ionic amorphous oxide semiconductors: Material design, carrier transport, and device application", J. Non-Cryst. Solids 352 (2006) 851.

[6] J.I. Jeong and J.H. Yang, "Optimization of coating conditions and room temperature deposition of ITO film using magnetron sputtering", RIST 22 (2008) 222.

[7 ] C.C. Lo and T.E. Hsieh, "Preparation of IGZO sputtering target and its applications to thin-film transistor devices", Ceram. Int. 38 (2012) 3977.

[8] H.K. Park, "The research and development trend of cathode materials in lithium ion battery", J. Korean
Electrochem. Soc. 11 (2008) 197.

[9] K.M. Ok, K.L. Kim, T.W. Kim, D.H. Kim, H.D. Park, Y.M. Sung, H.C. Park and S.Y. Yoon, "Preparation and characterization of $\mathrm{La}_{0.8} \mathrm{Sr}_{0.2} \mathrm{Ga}_{0.8} \mathrm{Mg}_{0.1} \mathrm{Co}_{0.1} \mathrm{O}_{3-\delta}$ electrolyte using glycine-nitrate process", J. Korean Cryst. Growth Cryst. Technol. 23 (2013) 37.

[10] T.W. Kim, D.H. Kim, H.H. Jin, H.S. Lee, H.C. Park and S.Y. Yoon, "Bioactivity behavior of biphasic calcium phosphate powders prepared by co-precipitation method", J. Korean Cryst. Growth Cryst. Technol. 22 (2012) 99.

[11] S.N. Choi and B.H. Lee, "Synthesis of the $\mathrm{Fe}_{2} \mathrm{O}_{3}-\mathrm{CoO}-$ $\mathrm{Cr}_{2} \mathrm{O}_{3}-\mathrm{MnO}_{2}$ pigments by co-precipitation method", J. Korean Cryst. Growth Cryst. Technol. 17 (2007) 264.

[12] K.C. Song, J.H. Kim and J.S. Sung, "Preparation of $\mathrm{SnO}_{2}$ powders by the precipitation method", J. Korean Inst. Chem. Eng. 35 (1997) 457.

[13] X. Liu, G. Qiu, Y. Zhao, N. Zhang and R. Yi, "Gallium oxide nanorods by the conversion of gallium oxide hydroxide nanorods", J. Alloys Compd. 439 (2007) 275.

[14] L. Li, W. Wei and M. Behrens, "Synthesis and characterization of $\alpha-, \beta-$, and $\gamma-\mathrm{Ga}_{2} \mathrm{O}_{3}$ prepared from aqueous solutions by controlled precipitation", Solid State Sci. 14 (2012) 971. 